\title{
Residual effects of successive exposure of soybean Bradyrhizobium strains to aluminium on solid defined medium(1)
}

\author{
Rubens José Campo (2) and Martin Wood(3)
}

\begin{abstract}
The aim of these studies was to investigate whether residual toxic effects of exposing soybean root nodule bacteria to $\mathrm{Al}$ in a solid defined media (SDM) alter tolerance to $\mathrm{Al}$, survival, sensitivity to antibiotics, $\mathrm{N}_{2}$ fixation effectiveness and genetic diversity of Bradyrhizobium strains. After being exposed four times to $\mathrm{Al}$, strains showed variation in $\mathrm{Al}$ tolerance but there was no evidence of change in their original Al tolerance, sensitivity to the antibiotics or genetic diversity. Exposure of Bradyrhizobium strains to SDM plus Al did not alter biological $\mathrm{N}_{2}$ fixation effectiveness of five strains. Strain SEMIA 587 showed a reduction in its $\mathrm{N}_{2}$ fixation effectiveness but it seems that it was just a superficial toxic effect because one single passage through the plant eliminated this effect. Residual Al did not cause increases in $\mathrm{Al}$ tolerance and reductions in the survival and $\mathrm{N}_{2}$ fixation effectiveness of Bradyrhizobium strains USDA 143, SEMIA 586, SEMIA 5019, SEMIA 5039 and SEMIA 5073. It also did not alter the resistance to antibiotics of strains USDA 143, SEMIA 5039 and SEMIA 5073, and the genetic diversity of the strains SEMIA 587 and SEMIA 5019.
\end{abstract}

Index terms: nitrogen fixation, antibiotics, resistance to chemicals, genetic variation.

Efeito residual de sucessivas exposições de estirpes de Bradyrhizobium da soja ao alumínio em meio de cultura sólido

\begin{abstract}
Resumo - O objetivo deste trabalho foi investigar se os efeitos tóxicos residuais do Al afetam a tolerância $\mathrm{Al}$, sobrevivência, sensibilidade a antibióticos, eficiência de fixação de nitrogênio e diversidade genética de estirpes de Bradyrhizobium. Quando os nódulos de bactérias da raiz de soja foram expostos ao Al, em meio sólido por quatro vezes consecutivas, as estirpes de Bradyrhizobium mostraram variações na tolerância ao Al. Não houve alterações nos níveis originais de tolerância ao Al, sobrevivência, sensibilidade aos antibióticos testados e diversidade genética. Cinco das estirpes expostas ao Al não alteraram a eficiência de fixação de nitrogênio. A estirpe SEMIA 587, por sua vez, mostrou uma redução da sua eficiência de fixação de $\mathrm{N}_{2}$, mas apenas superficial, porque uma simples passagem através da planta eliminou esse efeito tóxico. Sucessivas exposições de estirpes de Bradyrhizobium ao $\mathrm{Al}$ não aumentam a tolerância ao $\mathrm{Al}$, não reduzem a sobrevivência e a eficiência de fixação simbiótica do $\mathrm{N}_{2}$ das estirpes USDA 143, SEMIA 586, SEMIA 5019, SEMIA 5039 e SEMIA 5073, não alteram a tolerância a antibióticos das estirpes USDA 143, SEMIA 5039 e SEMIA 5073 e não alteram a diversidade genética das estirpes SEMIA 587 e SEMIA 5019.

Termos para indexação: fixação do nitrogênio, antibióticos, resistência a produtos químicos, variação genética.
\end{abstract}

(1) Accepted for publication on April 9, 2001.

Extracted from $\mathrm{Ph}$.D. thesis presented by the first author in the Department of Soil Science at The Reading University, Reading, UK.

(2)Embrapa-Centro Nacional de Pesquisa de Soja, Caixa Postal 231, CEP 86001-970 Londrina, PR, Brazil. E-mail: rjcampo@cnpso.embrapa.br

(3) The University of Reading, Department of Soil Science, P.O Box 233, Reading, RG6 6DW, UK. E-mail: m.wood@reading.ac.uk

\section{Introduction}

The efficiency of the interaction between Bradyrhizobium and soybean depends not only on bacteria and plant but also on a range of factors, such as toxic effects of acid soils ( $\mathrm{pH}, \mathrm{Mn}$ and $\mathrm{Al}$ ), soil nutrient levels (N, P, K, Ca, Mg and micronutrients), soil temperature, soil moisture and heavy metals. 
Studies regarding toxic effects of Al to Rhizobium and Bradyrhizobium have concentrated on selecting strains more Al tolerant. Little attention has been given to the effects of $\mathrm{Al}$ on the bacteria. Flis et al. (1993) presented an overview of the toxic effects of $\mathrm{Al}$ on the root nodule bacteria. There is uncertainty about which of the $\mathrm{Al}$ species is toxic to root nodule bacteria. Moreover, variation in the media used in different studies makes comparisons of effects of $\mathrm{Al}$ difficult. For example, any slight variation in $\mathrm{pH}$ will affect the ionic species of $\mathrm{Al}$ in the media.

Data showing the direct toxic effect of $\mathrm{Al}$ to the symbiotic process of $\mathrm{N}_{2}$ fixation in soybean have been reported by Alva et al. $(1987,1988)$ and Taylor et al. (1991). There are few reports of residual toxic effects of $\mathrm{Al}$ on the bacterium in culture media causing permanent alterations in its $\mathrm{N}_{2}$ fixing ability which have been linked to damage in its DNA (Johnson \& Wood, 1990) and mutagenesis (Octive et al., 1991, 1994).

The objective of this study was to investigate whether the successive exposure of Bradyrhizobium strains to $\mathrm{Al}$ on solid defined medium alters their survival, tolerance to $\mathrm{Al}$, antibiotic resistance, $\mathrm{N}_{2}$ fixation effectiveness and genetic diversity.

\section{Material and Methods}

\section{Selection, growth and maintenance of strains}

Bradyrhizobium japonicum strain USDA 143 from The Reading University, Bradyrhizobium japonicum strain SEMIA 586 and Bradyrhizobium elkanii strains (SEMIA 587, SEMIA 5019, SEMIA 5039 and SEMIA 5073) brought from Instituto de Pesquisas Agronômicas (Ipagro), Porto Alegre, RS, Brazil, were maintained at $4^{\circ} \mathrm{C}$ on yeast extract mannitol (YEM) agar plus $3 \mathrm{~g} \mathrm{~L}^{-1}$ of $\mathrm{CaCO}_{3}$ (Vincent, 1970). A loopful of each culture was aseptically transferred, streaked on sterile Petri dishes containing $20 \mathrm{~mL}$ of YEM agar and incubated at $26^{\circ} \mathrm{C}$ for colony development. Single colonies from each strain were picked up, grown in Universal bottles containing $10 \mathrm{~mL}$ of YEM broth and incubated at $26^{\circ} \mathrm{C}$ for eight days until turbidity. A loopful of each strain was transferred to slopes of YEM agar, incubated for at least eight days and stored at $4^{\circ} \mathrm{C}$.
Exposure of parental strains to Al on solid defined medium and selection of substrains

Each strain was aseptically transferred from YEM slopes to $10 \mathrm{~mL}$ of liquid defined medium (LDM) at pH 6.8 (Wood \& Cooper, 1988) and incubated till turbidity. A loopful of each culture was aseptically transferred, streaked on sterile Petri dishes containing $20 \mathrm{~mL}$ of solid defined medium (SDM) and incubated at $26^{\circ} \mathrm{C}$ for colony development. Three single colonies from each strain were selected randomly and grown in LDM to be used as inoculum (Figure 1). Simultaneously, sterile Petri dishes containing SDM at $\mathrm{pH} 5.5$ plus 12 different $\mathrm{Al}$ levels $(0$,

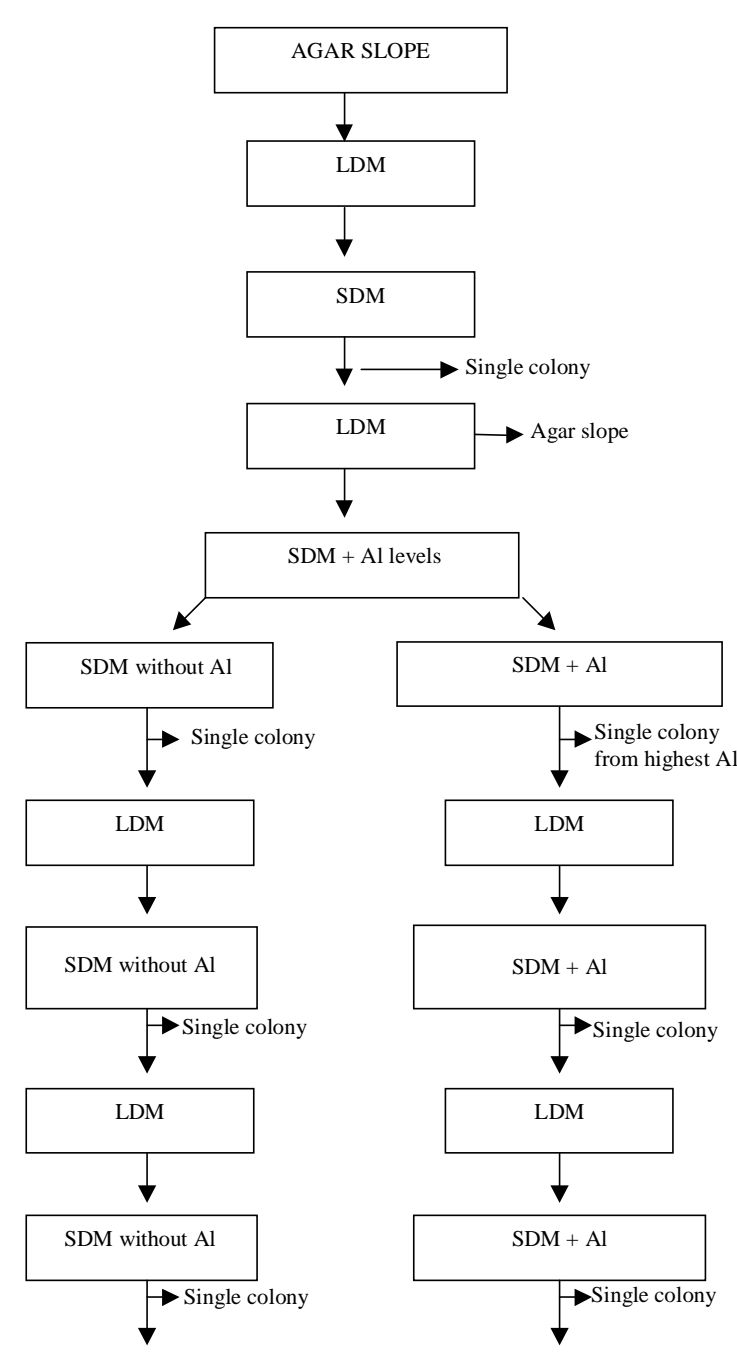

Figure 1. Procedure of exposing strains to $\mathrm{Al}$ and selecting substrains 
$50,100,150,200,250,300,350,400,450,500$ and $550 \mu \mathrm{M}$ ) were prepared and kept dry for two days (Ayanaba et al., 1983). Where required $\mathrm{Al}$ was added as a filter-sterilized solution of $50 \mu \mathrm{M} \operatorname{AlK}\left(\mathrm{SO}_{4}\right)_{2} \cdot 12 \mathrm{H}_{2} \mathrm{O}$. Duplicate plates of each $\mathrm{Al}$ level were inoculated and incubated for colony development. After 14 days, three single colonies from the SDM agar plates plus $0 \mu \mathrm{M} \mathrm{Al}$ (SDM without $\mathrm{Al}$ ) and three single colonies from the SDM agar plates plus the highest $\mathrm{Al}$ level $(\mathrm{SDM}+\mathrm{Al})$ which individual strains could tolerate (Figure 1) were selected and subcultured in LDM. The procedure of exposing these substrains to solid defined media without $\mathrm{Al}(\mathrm{SDM}-\mathrm{Al})$ or solid defined media with $\mathrm{Al}(\mathrm{SDM}+\mathrm{Al})$, selecting and subculturing substrains in LDM, was carried out for three more times (Figure 1). At the end of the fourth exposure to $\mathrm{Al}$, each parental strain had at least 90 substrains exposed to $\mathrm{SDM}$ without $\mathrm{Al}$ and 90 substrains exposed to $\mathrm{SDM}+\mathrm{Al}$

\section{Al tolerance and relative survival on SDM of strains exposed to Al}

Loopfuls of culture from: six substrains of each strain exposed four times to $\mathrm{SDM}+\mathrm{Al}$, six substrains of each strain exposed four times to SDM without $\mathrm{Al}$, and parental strains, were randomly and aseptically picked up from slopes (as described above), transferred to $10 \mathrm{~mL}$ of LDM and incubated at $26^{\circ} \mathrm{C}$ until turbidity developed. Simultaneously, sterile Petri dishes containing SDM $+\mathrm{Al}$ levels defined previously, were prepared and kept dry for two days. Duplicate plates of each Al level were inoculated with $80 \mu \mathrm{L}$ of a diluted cell culture $\left(10^{3} \mathrm{cfu} \mathrm{mL}^{-1}\right)$ and incubated at $26^{\circ} \mathrm{C}$ for colony development (Hoben \& Somasegaran, 1982). After 10 days, the number of colonies (diameter $0.5 \mathrm{~mm}$ ) was recorded daily during 25 days All treatments were done in duplicate. The relative growth of every strain or substrain at each $\mathrm{Al}$ level compared to the control (zero $\mathrm{Al}$ concentration) was calculated by dividing the number of colonies growing on each $\mathrm{SDM}+\mathrm{Al}$ level by the number of colonies growing at zero $\mathrm{Al}$ concentration. These values were expressed as a percentage.

\section{Antibiotic sensitivity of Bradyrhizobium substrains ex- posed to Al on SDM}

Loopfuls of cultures from substrains of the strains USDA 143, SEMIA 5039 and SEMIA 5073, exposed four times to $\mathrm{SDM}+\mathrm{Al}$ and four times to SDM without $\mathrm{Al}$, were randomly and aseptically picked up from slopes, transferred to $10 \mathrm{~mL}$ of LDM and incubated at $26^{\circ} \mathrm{C}$ until turbidity. Simultaneously, sterile Petri dishes containing YEM plus antibiotic levels were prepared and kept dry for two days. Antibiotics were obtained from Sigma Chemi- cal Co. Ltd, Poole, Dorset, UK and the stock solutions of rifampicin and kanamycin were prepared in distilled deionized water and dimethyl sulphoxide respectively. The antibiotics rifampicin $\left(0,25,50,100,150\right.$ or $\left.200 \mu \mathrm{g} \mathrm{mL}^{-1}\right)$ and kanamycin $\left(0,10,20\right.$ and $\left.40 \mu \mathrm{g} \mathrm{mL}^{-1}\right)$ were added to the YEM at $45^{\circ} \mathrm{C}$ as filter-sterilized solution just before adding the media to the Petri dishes. The Petri dishes were inoculated with $80 \mu \mathrm{L}$ of a diluted cell culture $\left(10^{3} \mathrm{cfu} \mathrm{mL} \mathrm{m}^{-1}\right)$ and incubated at $26^{\circ} \mathrm{C}$ for colony development. After eight days, the number of colonies (diameter $0.5 \mathrm{~mm}$ ) was scored daily during 25 days. For each substrain, the number of colonies growing on YEM + antibiotic level was expressed as a percentage of the number of colonies growing for that particular substrain on YEM without antibiotic All treatments were done in triplicate.

\section{$\mathbf{N}_{2}$ fixation effectiveness of substrains after following exposure to Al on SDM}

Loopfuls of cultures from parental strains, substrains exposed four times to $\mathrm{SDM}+\mathrm{Al}$ and substrains exposed four times to SDM without $\mathrm{Al}$ were randomly and aseptically picked up from slopes and transferred to $10 \mathrm{~mL}$ of $\mathrm{LDM}$ and incubated at $26^{\circ} \mathrm{C}$ until turbidity developed. Simultaneously, soybean seeds (cultivar BR-16) were surface-sterilized in $10 \%$ sodium hypochlorite for five minutes and pre-germinated in moist perlite. Similarly, sterile pots (1.2 L plastic containers) containing gravel plus vermiculite were prepared and received $200 \mathrm{~mL}$ of $\mathrm{N}$-free culture solution (Broughton \& Dilworth, 1970 cited by Somasegaran \& Hoben, 1985). One pre-germinated seed with $1.0-1.5 \mathrm{~cm}$ root length was then placed in the pot and treated with one mililiter of inoculum (concentration $10^{7}$ to $10^{8} \mathrm{cfu} \mathrm{mL}^{-1}$ ) from the culture above. Additional uninoculated pots, with or without $\mathrm{N}$, were included and received $1 \mathrm{~mL}$ of sterile LDM.

Soybean plants were grown in a controlled environment room at $26^{\circ} \mathrm{C}, 16$ hours light and 8 hours dark, for three weeks, then transferred to a greenhouse at temperature between 15 and $30^{\circ} \mathrm{C}$, using natural day light (minimum 13 hours) for more five weeks. The pots were weighed daily and a $\mathrm{N}$-free solution supplied as required. For the pots supplied with $\mathrm{N}, 400 \mathrm{mg}$ of N, was supplied weekly by adding $8 \mathrm{~mL}$ of a solution of $80 \mathrm{mg} \mathrm{N} \mathrm{mL}^{-1}$ of $\mathrm{NH}_{4} \mathrm{NO}_{3}$

Shoots were harvested after eight weeks by cutting at the base. They were dried for five days at $65^{\circ} \mathrm{C}$, weighed and ground for $\mathrm{N}$ analysis. The roots were harvested but due to the excessive nodulation the data was not presented. The $\mathrm{N}$ in the shoots was analyzed by double combustion $\left(\mathrm{O}_{2}\right.$ combustion at $1,000^{\circ} \mathrm{C}$ and a chromium trioxide at $1,000^{\circ} \mathrm{C}$ ) followed by a reduction to elemental $\mathrm{N}$ with cop- 
per at $600^{\circ} \mathrm{C}$ using a $\mathrm{N}$ analyzer (Europe Scientific, Robo Prep). Nitrogen fixation was estimated by subtracting the $\mathrm{N}$ in the shoots of uninoculated plants (without inorganic $\mathrm{N}$ ) from the $\mathrm{N}$ in the shoots of inoculated plants.

Six of the strains exposed to Al were tested in two separate experiments: strains USDA 143, SEMIA 587 , SEMIA 5073 and strains SEMIA 586, SEMIA 5019 , SEMIA 5039. These experiments were conducted at different times. The first one was done during a period of weather more favourable to the development of the plants, and for this reason they produced greater shoot dry weight and $\mathrm{N}$ yield than those in the second experiment. Both experiments were arranged as a completely randomized design with three replicates. Significance of treatment effects was assessed by analysis of variance (ANOVA) and significant differences between means were made using a $t$ test at $5 \%$ significance level and it was carried out only on the data for $\mathrm{N}$ fixed (column $\mathrm{N}$ uptake) because it integrated the other data.

\section{Genetic analysis by REP and ERIC primers}

The strains SEMIA 587 and SEMIA 5019 and substrains exposed to $\mathrm{Al}$ were chosen for genetic characterization because they have been used in commercial inoculants in Brazil. The genetic characterization of these strains was performed with bacterial genomic DNA amplified by the polymerase chain reaction technique (PCR). The primers used on the PCR performance were the repetitive extragenic palindromic (REP) and enterobacterial repetitive intergenic consensus (ERIC) sequences, as described by Bruijn (1992). The PCR patterns were recorded in the binary form, i.e., $1=$ presence of a band and $0=$ absence of a band to build a matrix. The hierarchical cluster analysis was calculated using UPGMA algorithm (Sarriés et al., 1994).

\section{Results and Discussion}

\section{Al tolerance and relative survival on SDM of strains exposed to Al on SDM}

Substrains from the strains used were exposed to different concentrations of $\mathrm{Al}$ up to 14 days and, the highest $\mathrm{Al}$ concentration that each strain could tolerate after one exposure to $\mathrm{Al}$ was considered, in this study, as the initial level of tolerance to $\mathrm{Al}$ (Table 1).

There was a variation in the initial $\mathrm{Al}$ tolerance among the strains (Table 1). Substrains from parental strains SEMIA 587 and SEMIA 5019 tolerated
$400 \mu \mathrm{M} \mathrm{Al}$ and substrains from strain USDA 143 tolerated $300 \mu \mathrm{M} \mathrm{Al}$. These strains appeared to be more tolerant to $\mathrm{Al}$ on SDM after 14 days of growth than the substrains from the parental strains SEMIA 586, SEMIA 5039 and SEMIA 5073 that tolerated $200 \mu \mathrm{M}$ Al. Similar results showing variation in Al tolerance among strains have been reported in data from experiments of attempts to select strains tolerant to Al (Keyser \& Munns, 1979a, 1979b; Taylor et al., 1991) and this is a genetic characteristic of strains. Similarly, in this work there was a variation in Al tolerance among strains. This means that the method used to expose strains to Al was efficient to separate $\mathrm{Al}$ tolerance. Examples of the efficiency of this methodology can be taken from the study of the tolerance among the five strains brought from Brazil. The strains SEMIA 587 and SEMIA 5019 selected as the most tolerant to $\mathrm{Al}$ in this study have been used in the composition of the soybean inoculants in acid soils from Brazil for more than 10 years (Peres \& Vidor, 1980).

The next step was to select colonies from these $\mathrm{Al}$ concentrations and expose them to the same concen-

Table 1. Aluminium tolerance $(\mu \mathrm{M})$ and relative growth (\%) of six strains of Bradyrhizobium (parental strains, strains exposed to SDM without $\mathrm{Al}$ and SDM with $\mathrm{Al}$ ) after being exposed to $\mathrm{Al}$ once and four times.

\begin{tabular}{lccccc}
\hline \multirow{2}{*}{$\begin{array}{c}\text { Strains of } \\
\text { Bradyrhizobium }\end{array}$} & \multicolumn{2}{c}{ First exposure } & & \multicolumn{2}{c}{ Fourth exposure } \\
\cline { 2 - 3 } \cline { 5 - 6 } & $\begin{array}{c}\mathrm{Al} \\
\text { tolerance }\end{array}$ & $\begin{array}{c}\text { Growth } \\
(\%)^{(1)}\end{array}$ & & $\begin{array}{c}\text { Al } \\
\text { tolerance }\end{array}$ & $\begin{array}{c}\text { Growth } \\
(\%)^{(1)}\end{array}$ \\
\hline USDA 143 & 300 & 107 & & 350 & 110 \\
SDM without Al & 300 & 101 & & 350 & 89 \\
SDM + Al & 300 & 102 & & 350 & 84 \\
\hline SEMIA 586 & 200 & 80 & & 350 & 72 \\
SDM without Al & 200 & 101 & & 350 & 104 \\
SDM + Al & 200 & 99 & & 350 & 101 \\
\hline SEMIA 587 & 400 & 96 & & 500 & 92 \\
SDM without Al & 400 & 99 & & 500 & 96 \\
SDM +Al & 400 & 100 & & 500 & 97 \\
\hline SEMIA 5019 & 400 & 103 & & 500 & 93 \\
SDM without Al & 400 & 100 & & 500 & 95 \\
SDM + Al & 400 & 99 & & 500 & 97 \\
\hline SEMIA 5039 & 200 & 87 & & 300 & 108 \\
SDM without Al & 200 & 102 & & 300 & 90 \\
SDM + Al & 200 & 107 & & 300 & 99 \\
\hline SEMIA 5073 & 200 & 95 & & 350 & 102 \\
SDM without Al & 200 & 99 & & 400 & 97 \\
SDM + Al & 200 & 102 & & 450 & 98 \\
\hline
\end{tabular}

(1)Number of colonies on SDM $+\mathrm{Al}$ expressed as a percentage of number of colonies on SDM without aluminium. 
tration of $\mathrm{Al}$ for more three times (e.g., substrains from strain USDA 143 were picked up from $300 \mu \mathrm{M} \mathrm{Al}$, subcultured in LDM and again exposed to $300 \mu \mathrm{M} \mathrm{Al}$ ). At the beginning, all the substrains exposed to $\mathrm{SDM}+\mathrm{Al}$ appeared to increase their $\mathrm{Al}$ tolerance until the second exposure to aluminium. Subsequently, exposures of substrains to Al showed an inhibitory effect of $\mathrm{Al}$ and did not show increases in the $\mathrm{Al}$ tolerance.

After the last exposure to Al, the strains exposed to $\mathrm{SDM}+\mathrm{Al}$ were tested at several concentrations of Al to measure their final tolerance and their relative survival on SDM $+\mathrm{Al}$ (Table 1). The Al tolerance of the parental strains and substrains grown on SDM without Al was also evaluated as well as their relative survival on $\mathrm{SDM}+\mathrm{Al}$. It seems that all the strains tested became more tolerant to $\mathrm{Al}$, but they did not. It occurred because the first exposure was recorded 14 days after inoculation and the fourth exposure was recorded 25 days after inoculation. The results showed that not only substrains exposed to Al but also parent strains and substrains exposed to $\mathrm{SDM}$ without $\mathrm{Al}$ presented the same $\mathrm{Al}$ tolerance; exception can be seen to the strain SEMIA 5073 that presented an increase in its $\mathrm{Al}$ tolerance. The parent strain tolerated $350 \mu \mathrm{M} \mathrm{Al}$ and the substrain exposed on $\mathrm{SDM}+\mathrm{Al}$ tolerated $450 \mu \mathrm{M} \mathrm{Al}$.

The relative growth (number of colonies on $\mathrm{SDM}+\mathrm{Al}$ expressed as a percentage of number of colonies on SDM without Al) of strain USDA 143 showed a reduction when its substrains were exposed to SDM without Al or SDM + Al $(300 \mu \mathrm{M})$, suggesting that this strain was more affected by SDM composition than the others. In contrast, parental strain SEMIA 586, showed a relative growth on $350 \mu \mathrm{M} \mathrm{Al}$ smaller than the substrains exposed to SDM + Al or SDM without aluminium. Strains SEMIA 587, SEMIA 5019 and SEMIA 5039 did not show any differences in their relative growth and in their tolerance to aluminium. On the other hand, SEMIA 5073 showed different results. Exposure of substrains to SDM without $\mathrm{Al}$ and especially substrains exposed to $\mathrm{SDM}+200 \mu \mathrm{M}$ Al showed a slight increase in their Al tolerance; however, it did not show decrease in the relative growth even when substrains were exposed to $\mathrm{SDM}+\mathrm{Al}$ for four times.

In contrast to these results, data presented by Octive (1990) reported that strain USDA 143 showed increase in tolerance to $\mathrm{Al}$ on SDM from $450 \mu \mathrm{M} \mathrm{Al}$ to $950 \mu \mathrm{M} \mathrm{Al}$ after four exposures to aluminium. The most likely hypothesis to explain the differences between those results and ours is the difference in the final $\mathrm{pH}$ of the defined medium. Both studies followed the methods described by Ayanaba et al. (1983). In the present studies, it was found that the addition of $\mathrm{Al}$ decreased the $\mathrm{pH}$ of the media, similar to the studies of Ayanaba et al. (1983). It was found, for example, that increases of $\mathrm{Al}$ from $0 \mu \mathrm{M}$ Al to $500 \mu \mathrm{M} \mathrm{Al}$ decreased $\mathrm{pH}$ from 5.50 to $5.0 \pm 0.04$. In the present study, the $\mathrm{pH}$ was not adjusted to the initial $\mathrm{pH}$ (pH 5.5) as proposed by Ayanaba et al. (1983). In the study by Octive (1990) the $\mathrm{pH}$ of the medium was returned to the original $\mathrm{pH}$ after addition of the different concentrations of aluminium. So, both studies were done at the same initial $\mathrm{pH}$ but at different resultant $\mathrm{pH}$. Differences in $\mathrm{pH}$ of solutions alters the presence and concentration of the $\mathrm{Al}$ species in the solution by reactions of dissolution and precipitation of solid or liquid phases of Al (Lindsay \& Walthall, 1989; Ritchie, 1989, 1994), and could have led to the different results reported.

\section{Antibiotic sensitivity of Bradyrhizobium substrains exposed to Al on SDM}

The results of the antibiotic sensitivity of substrains exposed or not to $\mathrm{Al}$ are presented in Table 2. From the parental strains USDA 143, SEMIA 5039 and SEMIA 5073 two substrains were chosen to measure antibiotic sensitivity: one exposed to SDM without $\mathrm{Al}$ and the other one exposed four times to SDM $+300 \mu \mathrm{M} \mathrm{Al}$ (substrain USDA 143) or $200 \mu \mathrm{M}$ Al (substrains SEMIA 5039 and SEMIA 5073). There was a large difference in the antibiotic resistance among substrains, even when SEMIA 5073 (which showed an increase in Al tolerance) was tested (Table 2). The substrains from strain USDA 143, exposed or not to Al, tolerated a maximum of $25 \mu \mathrm{g} \mathrm{mL}^{-1}$ of rifampicin and $10 \mu \mathrm{g} \mathrm{mL}^{-1}$ of kanamycin. The substrains from strain SEMIA 5039, tolerated $150 \mu \mathrm{g} \mathrm{mL}^{-1}$ of rifampicin and $20 \mu \mathrm{g} \mathrm{mL}^{-1}$ of kanamycin. The substrains from strain SEMIA 5073 tolerated $150 \mu \mathrm{g} \mathrm{mL}^{-1}$ of rifampicin and $10 \mu \mathrm{g} \mathrm{mL}^{-1}$ of kanamycin. There were no differences between substrains exposed to $\mathrm{SDM}+\mathrm{Al}$ or $\mathrm{SDM}$ without $\mathrm{Al}$ in their sensitivity to rifampicin and 
kanamycin. These results suggest that the levels of $\mathrm{Al}$ applied did not affect the sensitivity to antibiotics of three substrains evaluated. These data are in agreement with Ayanaba \& Wong (1982) who also observed that the resistance to antibiotics did not necessarily entail tolerance to $\mathrm{Al}$ although in their study strains from acid soils tend to be more resistant to antibiotics. They concluded that there was no evidence of cross-resistance to $\mathrm{Al}$ and antibiotics in Bradyrhizobium.

\section{$\mathbf{N}_{\mathbf{2}}$ fixation effectiveness of substrains exposed to SDM + Al}

Table 3 presents data for soybean, cv. BR-16, inoculated with one parental strain of strains USDA 143, SEMIA 587 and SEMIA 5073; one substrain from each strain exposed four times to SDM without $\mathrm{Al}$; and two substrains from each strain exposed four times to SDM + Al (USDA 143, $300 \mu \mathrm{M} \mathrm{Al}$; SEMIA 587, $400 \mu \mathrm{M} \mathrm{Al}$ and SEMIA 5073, $200 \mu \mathrm{M} \mathrm{Al}$ ). N yield mean of parental SEMIA 587 and its substrain exposed to SDM without $\mathrm{Al}$ was higher than $\mathrm{N}$ yield mean of both substrains of SEMIA 587 exposed to $400 \mu \mathrm{M} \mathrm{Al}$ This indicates that prior exposure of this strain to $\mathrm{Al}$ affected the $\mathrm{N}_{2}$ fixation effectiveness of this strain. Nodules of this substrain were collected, the substrains isolated and used in a further study to in- vestigate their nodulation ability, $\mathrm{N}_{2}$ fixation effectiveness and also to determine if after one passage through the plant this effect would disappear. Table 4 presents data for shoot dry weight, $\mathrm{N}$ in the plant, $\mathrm{N}$ yield, nodule number and nodule dry weight between the two substrains. There were no differences between parental strain and an isolate taken from a nodule formed by a substrain that received four single exposures to $\mathrm{SDM}+400 \mu \mathrm{M}$ Al. This result indicated that, if Al really gave any residual effect on strain SEMIA 587, one passage through the plant eliminated that possible initial toxic effect of aluminium. It seems that the initial effect caused by $\mathrm{Al}$ was a temporary one and not an effect on the nif genes as suggested by Octive (1990) and Octive et al. (1994). Other strains tested at the same time (USDA 143 and SEMIA 5073) in this experiment did not show any lasting effect of exposure to aluminium.

Table 5 presents data for soybean plants inoculated with one parental strains of strains SEMIA 586, SEMIA 5019 and SEMIA 5039; one substrain from each parental strain exposed four times to SDM without $\mathrm{Al}$; and two substrains from each parental strain exposed four times to SDM + Al (SEMIA 586, $200 \mu \mathrm{M} \mathrm{Al}$; SEMIA 5019, $400 \mu \mathrm{M} \mathrm{Al}$, and SEMIA 5039, $200 \mu \mathrm{M} \mathrm{Al}$ ). Strains SEMIA 586, SEMIA 5019 and SEMIA 5039 did not show any lasting effects of exposure to Al because substrains

Table 2. Relative growth (number of colonies on YEMA + antibiotic expressed as a percentage of number of colonies on YEM $+0 \mu \mathrm{g} \mathrm{mL}{ }^{-1}$ antibiotic) of Bradyrhizobium japonicum substrains on YEMA + antibiotic, after being exposed four times to SDM without $\mathrm{Al}$ and four times to SDM + $\mathrm{Al}$ (strain USDA 143 on $300 \mu \mathrm{M}$ Al and strains SEMIA 5039 and SEMIA 5073 on $200 \mu \mathrm{M} \mathrm{Al}$ ). Three replicates per average.

\begin{tabular}{|c|c|c|c|c|c|c|}
\hline \multirow{2}{*}{$\begin{array}{l}\text { Antibiotic concentration } \\
\qquad\left(\mu \mathrm{g} \mathrm{mL}^{-1}\right)\end{array}$} & \multicolumn{2}{|c|}{ USDA 143} & \multicolumn{2}{|c|}{ SEMIA 5039} & \multicolumn{2}{|c|}{ SEMIA 5073} \\
\hline & $0 \mu \mathrm{M}$ & $300 \mu \mathrm{M}$ & $0 \mu \mathrm{M}$ & $200 \mu \mathrm{M}$ & $0 \mu \mathrm{M}$ & $200 \mu \mathrm{M}$ \\
\hline & \multicolumn{6}{|c|}{ Rifampicin } \\
\hline 0 & 100.0 & 100.0 & 100.0 & 100.0 & 100.0 & 100.0 \\
\hline 25 & 8.7 & 7.8 & $\mathrm{~N}^{(1)}$ & $\mathrm{N}$ & $\mathrm{N}$ & $\mathrm{N}$ \\
\hline 50 & 0.5 & 0.4 & 46.6 & 49.2 & 46.1 & 40.0 \\
\hline 100 & 0.0 & 0.0 & 19.8 & 24.9 & 8.7 & 5.7 \\
\hline \multirow[t]{2}{*}{150} & 0.0 & 0.0 & 6.1 & 8.2 & 3.6 & 2.1 \\
\hline & \multicolumn{6}{|c|}{ Kanamycin } \\
\hline 0 & 100.0 & 100.0 & 100.0 & 100.0 & 100.0 & 100.0 \\
\hline 10 & 90.3 & 78.7 & 60.3 & 83.4 & 1.2 & 4.8 \\
\hline 20 & 0.0 & 0.0 & 30.3 & 33.0 & 0.0 & 0.0 \\
\hline 40 & 0.0 & 0.0 & 0.0 & 0.0 & 0.0 & 0.0 \\
\hline
\end{tabular}

(1)Not inoculated. 
exposed to $\mathrm{SDM}+\mathrm{Al}$ or to SDM without $\mathrm{Al}$ showed similar results.

Data showing the direct toxic effect of $\mathrm{Al}$ on the symbiotic process of $\mathrm{N}_{2}$ fixation in soybean are frequently reported (Flis et al., 1993). Reports of re-

Table 3. Soybean shoot dry weight, $\mathrm{N}$ in the shoots and $\mathrm{N}$ yield of Bradyrhizobium japonicum parental strains (USDA 143, SEMIA 587 and SEMIA 5073), substrains B exposed to SDM without $\mathrm{Al}$ and substrains $\mathrm{C}$ and $\mathrm{D}$ exposed to $\mathrm{SDM}+\mathrm{Al}$. Three replicates per average.

\begin{tabular}{|c|c|c|c|c|}
\hline Substrains & $\begin{array}{c}\text { Al concentracion } \\
(\mu \mathrm{M})\end{array}$ & $\begin{array}{l}\text { Shoot dry } \\
\text { weight }(\mathrm{g})\end{array}$ & $\begin{array}{c}\mathrm{N} \text { shoots } \\
(\%)\end{array}$ & $\begin{array}{l}\mathrm{N} \text { yield } \\
(\mathrm{mg})^{(1)}\end{array}$ \\
\hline USDA 143 (A) & - & 43.5 & 2.56 & $1,113.3 \mathrm{a}$ \\
\hline USDA 143 (B) & 0 & 43.3 & 2.71 & $1,172.2 \mathrm{a}$ \\
\hline USDA 143 (C) & 300 & 46.0 & 2.50 & $1,151.3 \mathrm{a}$ \\
\hline USDA 143 (D) & 300 & 44.3 & 2.49 & $1,102.6 a$ \\
\hline $\operatorname{Mean}(\mathrm{A}+\mathrm{B})^{(2)}$ & - & 43.4 & 2.64 & $1,142.8$ \\
\hline $\operatorname{Mean}(C+D)^{(3)}$ & - & 45.2 & 2.50 & $1,127.0$ \\
\hline LSD & & & & 130.6 \\
\hline SEMIA 587 (A) & - & 44.8 & 2.48 & $1,109.7 \mathrm{a}$ \\
\hline SEMIA 587 (B) & 0 & 45.2 & 2.22 & $1,003.9 b$ \\
\hline SEMIA 587 (C) & 400 & 39.7 & 2.30 & $913.6 b$ \\
\hline SEMIA 587 (D) & 400 & 43.9 & 2.24 & $983.3 b$ \\
\hline $\operatorname{Mean}(\mathrm{A}+\mathrm{B})^{(2)}$ & - & 45.0 & 2.35 & $1,056.8 \mathrm{~A}$ \\
\hline $\operatorname{Mean}(C+D)^{(3)}$ & - & 41.8 & 2.27 & $948.5 \mathrm{~B}$ \\
\hline LSD & & & & 101.7 \\
\hline SEMIA 5073 (A) & - & 43.2 & 2.73 & $1,181.0 \mathrm{a}$ \\
\hline SEMIA 5073 (B) & 0 & 44.6 & 2.80 & $1,250.4 \mathrm{a}$ \\
\hline SEMIA 5073 (C) & 200 & 42.8 & 2.78 & $1,188.6 \mathrm{a}$ \\
\hline SEMIA 5073 (D) & 200 & 42.7 & 2.77 & $1,181.7 \mathrm{a}$ \\
\hline Mean $(\mathrm{A}+\mathrm{B})^{(2)}$ & - & 43.9 & 2.77 & $1,215.7$ \\
\hline Mean $(C+D)^{(3)}$ & - & 42.8 & 2.78 & $1,185.2$ \\
\hline LSD & & & & 116.9 \\
\hline Not inoculated & - & 0.34 & 0.59 & 2.0 \\
\hline Nitrogen & - & 23.8 & 1.59 & 378.4 \\
\hline
\end{tabular}

(1)Values followed by the same letter in the same column, from each strain, do not differ among themselves ( $\mathrm{t}$ test, $\mathrm{p} \leq 0.05$ ). ${ }^{(2)}$ Mean between the strain and substrain not exposed to aluminium. ${ }^{(3)}$ Mean between the two substrains exposed to aluminium.

Table 4. Soybean data of dry shoot, $\mathrm{N}$ in the shoots, $\mathrm{N}$ yield, number and weight of nodules from one parental strain SEMIA 587 and one isolate substrain from strain SEMIA 587 isolated from a nodule of a plant inoculated with a substrain exposed four times to SDM $+400 \mu \mathrm{M} \mathrm{Al}$ Four replicates per average

\begin{tabular}{lcc}
\hline Parameter & $\begin{array}{c}\text { Parental strain } \\
\text { SEMIA 587 }\end{array}$ & $\begin{array}{c}\text { Isolate substrain } \\
\text { SEMIA 587 }\end{array}$ \\
\hline Dry shoot (g) & 20.8 & 20.2 \\
N shoots (\%) & 2.3 & 2.4 \\
N yield (mg) & 479.5 & 474.9 \\
Nodule number & 376.3 & 374.5 \\
Nodule weight (g) & 1.8 & 2.0 \\
\hline
\end{tabular}

sidual or lasting effects of $\mathrm{Al}$ on the bacteria causing alterations in $\mathrm{N}_{2}$ fixation of Bradyrhizobium are rare. Octive et al. (1994) reported that single exposures of parental strain USDA 148 to $450 \mu \mathrm{M} \mathrm{Al}$ reduced nodulation and $\mathrm{N}_{2}$ fixation of most of the substrains. The data presented in this study are from 12 substrains of six parental strains of Bradyrhizobium and did not show any residual effects following four single exposures to aluminium.

\section{Genetic characteristics of strains SEMIA 587 and SEMIA 5019 and their substrains exposed to Al on SDM}

The genomic DNA of two parental strains of Bradyrhizobium as well as three substrains of each parental strain exposed to $\mathrm{Al}$ in SDM were used as templates for REP and ERIC PCR patterns. As can be seen in Figure 2, using REP and ERIC primers

Table 5. Soybean shoot dry weight, $\mathrm{N}$ in the shoots and $\mathrm{N}$ yield of Bradyrhizobium japonicum parental strains (SEMIA 586, SEMIA 5019 and SEMIA 5039), substrains $\mathrm{B}$ exposed to SDM without $\mathrm{Al}$ and substrains $\mathrm{C}$ and $\mathrm{D}$ exposed to SDM $+\mathrm{Al}$. Three replicates per average.

\begin{tabular}{|c|c|c|c|c|}
\hline Substrains & $\begin{array}{c}\text { Al concentracion } \\
(\mu \mathrm{M})\end{array}$ & $\begin{array}{l}\text { Shoot dry } \\
\text { weight }(g)\end{array}$ & $\begin{array}{c}\mathrm{N} \text { shoots } \\
(\%)\end{array}$ & $\begin{array}{l}\text { N yield } \\
(\mathrm{mg})^{(1)}\end{array}$ \\
\hline USDA 143 (A) & - & 29.8 & 2.06 & $614.2 \mathrm{a}$ \\
\hline USDA 143 (B) & 0 & 30.1 & 1.99 & $597.7 \mathrm{a}$ \\
\hline USDA 143 (C) & 300 & 30.5 & 1.87 & $571.4 \mathrm{a}$ \\
\hline USDA 143 (D) & 300 & 29.8 & 2.00 & $597.7 \mathrm{a}$ \\
\hline $\operatorname{Mean}(\mathrm{A}+\mathrm{B})^{(2)}$ & - & 30.0 & 2.03 & 606.0 \\
\hline $\operatorname{Mean}(C+D)^{(3)}$ & - & 30.2 & 1.94 & 584.6 \\
\hline LSD & & & & 66.4 \\
\hline SEMIA 587 (A) & - & 23.9 & 1.44 & $344.2 \mathrm{a}$ \\
\hline SEMIA 587 (B) & 0 & 24.2 & 1.59 & $384.3 \mathrm{a}$ \\
\hline SEMIA 587 (C) & 400 & 22.2 & 1.74 & $385.1 \mathrm{a}$ \\
\hline SEMIA 587 (D) & 400 & 24.4 & 1.44 & $350.7 \mathrm{a}$ \\
\hline $\operatorname{Mean}(\mathrm{A}+\mathrm{B})^{(2)}$ & - & 24.1 & 1.52 & 364.3 \\
\hline $\operatorname{Mean}(C+D)^{(3)}$ & - & 23.3 & 1.59 & 367.9 \\
\hline LSD & & & & 46.4 \\
\hline SEMIA 5073 (A) & - & 27.9 & 1.98 & $551.7 \mathrm{a}$ \\
\hline SEMIA 5073 (B) & 0 & 29.1 & 1.96 & $570.6 \mathrm{a}$ \\
\hline SEMIA 5073 (C) & 200 & 26.6 & 1.96 & $520.5 \mathrm{a}$ \\
\hline SEMIA 5073 (D) & 200 & 27.5 & 2.01 & $551.0 \mathrm{a}$ \\
\hline Mean $(A+B)^{(2)}$ & - & 28.5 & 1.97 & 561.2 \\
\hline $\operatorname{Mean}(\mathrm{C}+\mathrm{D})^{(3)}$ & - & 27.1 & 1.98 & 535.8 \\
\hline LSD & & & & 57.9 \\
\hline Not inoculated & - & 0.33 & 0.70 & 2.3 \\
\hline Nitrogen & - & 33.1 & 1.77 & 583.6 \\
\hline
\end{tabular}

Pesq. agropec. bras., Brasília, v. 36, n. 11, p. 1399-1407, nov. 2001 


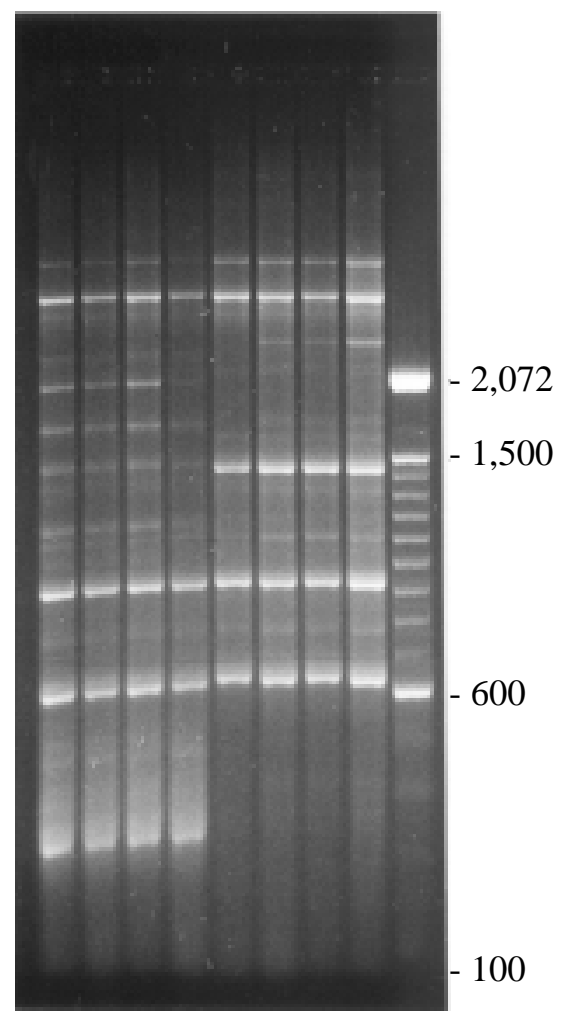

$\begin{array}{lllllllll}1 & 2 & 3 & 4 & 5 & 6 & 7 & 8 & \mathrm{~S}\end{array}$ REP

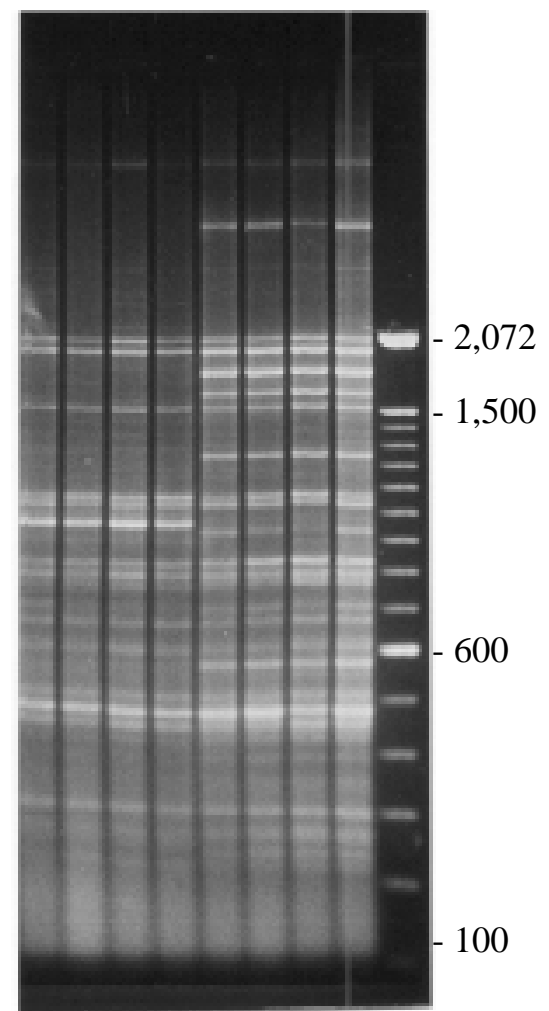

$\begin{array}{lllllllll}1 & 2 & 3 & 4 & 5 & 6 & 7 & 8 & \mathrm{~S}\end{array}$

ERIC

Figure 2. REP and ERIC PCR fingerprint patterns showing the comparison of genomic DNA of parental strains SEMIA 587 (lane 1) and SEMIA 5019 (lane 5). Lanes 2, 3 and 4 are SEMIA 587 isolates exposed to $\mathrm{Al}$ and lanes 6, 7 and 8 are SEMIA 5019 isolates exposed to Al. Lanes S show the molecular weight markers.

and REP technique, it was possible to distinguish the differences between the parental strains SEMIA 587 and SEMIA 5019 and their substrains exposed to Al on SDM. Separate cluster analyses with each set of data are shown for each strain by REP and ERIC primers (Figure 2). The genetic similarity coefficient derived from PCR fingerprints generated by both primers of both strains and substrains were tested but not included because genetic differences between each strain and their substrain exposed to Al were not detected by PCR technique performed with the primers REP and ERIC.

The results of this study indicate that REP and ERIC PCR patterns provide a high degree of discrimination between strains SEMIA 587 and
SEMIA 5019, and that the exposure to Al did not affect the PCR patterns evaluated by REP and ERIC PCR techniques. Previous work of Nishi et al. (1996), using the same technique, demonstrated genetic differences between parental strains and variant strains of Bradyrhizobium.

\section{Conclusions}

1. Exposure of Bradyrhizobium strains USDA 143, SEMIA 586, SEMIA 587, SEMIA 5019, SEMIA 5039 and SEMIA 5073 to SDM plus Al do not cause change on their Al tolerance, survival, resistance to antibiotics and $\mathrm{N}_{2}$ fixation effectiveness. 
2. The genetic characteristics of strains SEMIA 587 and SEMIA 5019 determined by REP and ERIC PCR do not change as a function of $\mathrm{Al}$ exposure.

\section{References}

ALVA, A. K.; EDWARDS, D. G.; ASHER, C. J.; SUTHIPRADIT, S. Effects of acid soil infertility factors on growth and nodulation of soybean. Agronomy Journal, Madison, v. 79, p. 302-306, 1987.

ALVA, A. K.; EDWARDS, D. G.; CARROL, B. J.; ASHER, C. J.; GRESSHOFF, S. Nodulation and early growth of soybean mutants with increased nodulation capacity under acid soil infertility factors. Agronomy Journal, Madison, v. 80, p. 836-841, 1988

AYANABA, A.; ASANUMA, S.; MUNNS, D. N. An agar plate method for rapid screening of Rhizobium for tolerance to acid-aluminium stress. Soil Science Society of America Journal, Madison, v. 47, p. 256-258, 1983

AYANABA, A.; WONG,A. L. Antibiotic-resistant mutants identified from nodules of uninoculated soybean grown in a strongly acid soil. Soil Biology and Biochemistry, Oxford, v. 14, p. 139-143, 1982.

BRUIJN, F. J. de. Use of repetitive (repetitive extragenic palindromic and enterobacterial repetitive intergenic consensus) sequences and polymerase chain reaction to fingerprint the genomes of Rhizobium meliloti isolates and other soil bacteria. Applied and Environmental Microbiology, Washington, v. 58, p. 2180-2187, 1992.

FLIS, S. E.; GLENN, A. R.; DILWORTH, J. The interaction between aluminium and root nodule bacteria. Soil Biology and Biochemistry, Oxford, v. 25, p. 403-417, 1993

HOBEN, H. J.; SOMASEGARAN, P. Comparison of the pour, spread and drop plate methods for enumeration of Rhizobium spp. in inoculants made from presterilized peat Applied and Environmental Microbiology, Washington, v. 44 , p. $1246-1247,1982$.

JOHNSON, A. C.; WOOD, M. DNA: a possible site of action of aluminium in Rhizobium spp. Applied and Environmental Microbiology, Washington, v. 26, p. 36293633, 1990.

KEYSER, H. H.; MUNNS, D. N. Effects of calcium, manganese, and aluminium on growth of rhizobia in acid media. Soil Science Society of America Journal, Madison, v. 43 , p. $500-503,1979 a$.

KEYSER, H. H.; MUNNS, D. N. Tolerance of rhizobia to acidity, aluminium and phosphate. Soil Science Society of America Journal, Madison, v. 43, p. 519-523, 1979b.
LINDSAY, W. L.; WALTHALL, P. M. The solubility aluminum in soils. In: SPOSITO, G. (Ed.). The environmental chemistry of aluminum. Boca Raton: CRC, 1989. p. 221-239

NISHI, C. Y. M.; BODDEY, L. H.; VARGAS, M. A. T.; HUNGRIA, M. Morphological, physiological and genetic characterization of two new Bradyrhizobium strains recently recommended as Brazilian commercial inoculants for soybean. Symbiosis, Rehovot, v. 20, p. 147-162, 1996.

OCTIVE, J. C. Mutagenic effects of aluminium on rhizobia and bradyrhizobia. Reading: The University of Reading, 1990. 207 p. Ph.D. Thesis.

OCTIVE, J. C.; JOHNSON, A.; WOOD, M. Effects of previous aluminium exposure on motility and nodulation by Rhizobium and Bradyrhizobium. Soil Biology and Biochemistry, Oxford, v. 26, p. 1477-1482, 1994

OCTIVE, J. C.; WOOD, M.; JOHNSON, A. C. Mutagenic effects of aluminium. Mutation Research, Amsterdam, v. 264 , p. $135-137,1991$

PERES, J. R. R.; VIDOR, C. Seleção de estirpes de Rhizobium japonicum e competitividade por sítios de infecção nodular em cultivares de soja. Agronomia Sulriograndense, Santa Maria, v. 16, n. 2, p. 205-219, 1980

RITCHIE, G. S. P. Role of dissolution and precipitation of minerals in controlling soluble aluminium in acid soils. Advances in Agronomy, New York, v. 53, p. 47-83, 1994.

RITCHIE, G. S. P. The chemical behaviour of aluminium, hydrogen and manganese in acid soils. In: ROBSON,A. D. (Ed.). Soil acidity and plant growth. Sydney:Academic, 1989. p. 1-60.

SARRIÉS, G. A.; WALTER, M.; REYS, A. E. L.; MOON, $D$. Numerical taxonomy and multivariate analysis system. Piracicaba: USP, 1994. 7 p.

SOMASEGARAN, P.; HOBEN, H. J. Methods in legumerhizobium technology. Maui: University of Hawaii/ NifTAL Project and MIRCEN, 1985. 367 p.

TAYLOR, R. W.; WILLIAMS, M. L.; SISTANI, K. R. $\mathrm{N}_{2}$ fixation by soybean-Bradyrhizobium combinations under acidity, low $\mathrm{P}$ and high $\mathrm{Al}$ stresses. In: WRIGHT, R. J.; BALIGAR, V. C.; MURRMANN, R. P. (Ed.). Plantsoil interactions at low pH. Dordrecht: Kluwer, 1991. p. 293-300

VINCENT, J. M. A manual for the practical study of root-nodule bacteria. Oxford: Blackwell Scientific, 1970. $164 \mathrm{p}$

WOOD, M.; COOPER, J. E. Acidity, aluminium and multiplication of Rhizobium trifolii: effects of initial inoculum density and growth phase. Soil Biology and Biochemistry, Oxford, v. 20, p. 83-87, 1988.

Pesq. agropec. bras., Brasília, v. 36, n. 11, p. 1399-1407, nov. 2001 